\title{
ДИСКУССИИ
}

DOI: https://doi.org/10.15688/jvolsu2.2021.3.14

UDC 81'1:791

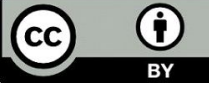

LBC 81.006

Submitted: 25.01 .2020

Accepted: 16.02 .2021

\section{MOTION PICTURES AS A SOURCE OF EMPIRICAL LANGUAGE DATA (A CASE STUDY OF COUNTERFACTUALS)}

\author{
Andrey S. Druzhinin \\ MGIMO University, Moscow, Russia
}

\begin{abstract}
The article focuses on the problem of research methodology in linguistics and argues that motion pictures, or feature films, provide a good source of empirical data for a realistic investigation of language as a communicative behavior. Evidence from epistemology and philosophy of science shows that scriptism and rationalism as two dominating methodologies in traditional linguistics do not give a whole picture of language functionality because through them we cannot observe a human's communicative behavior in dynamics. The aim of the article is to offer an alternative understanding of the subject-matter, method and data for linguistic research which would be grounded on human experience observable in films. In particular, the term 'languaging' is adopted to describe the dynamic process of experience construction in referential and attentional framings. The investigation of languaging is thus based on the principle of holism, circularity and 'double perspectival' view of one's experience. The author of the article gives a number of reasons why written texts alone do not provide reliable data in this respect and why motion pictures are a more viable alternative. The paper introduces the methodology of holistic research and openended experiential analysis and demonstrates in a case study how counterfactuals as grammatically and experientially enacted patterns can be observed and investigated in the film Atonement.
\end{abstract}

Key words: experience construction, experiential context, motion pictures, languaging, enactivism, holism.

Citation. Druzhinin A.S. Motion Pictures as a Source of Empirical Language Data (A Case Study of Counterfactuals). Vestnik Volgogradskogo gosudarstvennogo universiteta. Seriya 2. Yazykoznanie [Science Journal of Volgograd State University. Linguistics], 2021, vol. 20, no. 3, pp. 166-175. DOI: https://doi.org/10.15688/jvolsu2.2021.3.14

\section{КИНОФИЛЬМ КАК ИСТОЧНИК ЭМПИРИЧЕСКИХ ДАННЫХ О ЯЗЫКЕ (НА ПРИМЕРЕ КОНТРФАКТУАЛЬНЫХ ВЫСКАЗЫВАНИЙ)}

\section{Андрей Сергеевич Дружинин}

Московский государственный институт международных отношений (университет) МИД России, г. Москва, Россия

Аннотация. Статья затрагивает проблему методологии в науке о языке. Установлено, что художественные фильмы предоставляют адекватные эмпирические данные, необходимые для реалистичного изучения языка как коммуникативного поведения человека. Доводы эпистемологии и философии науки свидетельствуют о том, что методология «скриптизма» и рационализма, до сих пор востребованных в лингвонаучной практике, не способна раскрыть сущность языка, поскольку она не дает возможности наблюдать коммуникативное поведение человека в динамике. Цель данной статьи - предложить альтернативное понимание предмета, метода 
и эмпирического материала лингвистического исследования, в центре внимания которого будет опыт человека, доступный для наблюдения посредством динамики видеоряда. Вводится и объясняется термин «языковое поведение» (languaging), обозначающий процесс конструирования человеком своего опыта в динамике меняющихся объектов внимания и референции. Утверждается, что изучение языкового поведения основывается на принципах холизма, циркулярности и диалектического взгляда на опыт человека. Автор статьи приводит ряд доводов, объясняющих, почему в такой исследовательской парадигме одни только тексты не могуг выступать в качестве надежного источника данных о языке и почему фильмы являются лучшей альтернативой. На примере кинофильма «Искупление» демонстрируется, как фильм, изучаемый в ракурсе предлагаемого подхода, помогает раскрыть экспериенциальную сущность определенного грамматического явления.

Ключевые слова: конструирование опыта, экспериенциальный контекст, игровые картины, поведение в языке, энактивизм, холизм.

Цитирование. Дружинин А. С. Кинофильм как источник эмпирических данных о языке (на примере контрфактуальных высказываний) // Вестник Волгоградского государственного университета. Серия 2, Языкознание. - 2021. - Т. 20, № 3. - С. 166-175. - (На англ. яз.). - DOI: https://doi.org/10.15688/jvolsu2.2021.3.14

\section{Introduction}

Why sciences are concerned with the dynamics of experience. As Paul Valéry put it, "science is the collection of recipes that work always" [Valéry, 1957, p. 1253]. Any scientific research sets out to explore things and processes. By doing so, a scientist pursues the goal of explaining how they function to make sure he / she knows when, how and where they happen. It is the knowledge of these conditions that provides a truly scientific understanding and definition of what things and processes are. It is what "our faith in science rests upon" [Valéry, 1957, p. 1253].

We cannot refer to things and processes independent of what we do. The Nobel Prize winner Percy Bridgman in his The Logic of Modern Physics (1927) made a case for the operational origin of all fundamental concepts of time, space, length, etc., and the respective terms used by science. "The true meaning of a term is to be found by observing what a man does with it (emphasis added. $-A$. D.), not by what a man says about it" [Bridgman, 1958, p. 7].

Later, Humberto Maturana [1988] in his philosophy of cognition maintained that reality, however objective it might seem, has biological roots in ourselves - more precisely, in our doings. What we call the phenomena of reality are but our experiences. 'What is this or that thing or how does it happen?' is not what we should ask ourselves in an effort to unearth the truth of reality. Instead, questions like 'What do I do when I distinguish a thing?' are more scientifically effective [Maturana, 2012]. For example, to investigate and define a concept in physics, psychology or chemistry one must isolate an object of observation, propose a hypothesis explaining how, where and when the phenomenon is, and is to be, repeatedly observed, and then put this hypothesis to 'life test' to check if it fits the real experiential situation [Glasersfeld, 1995, p. 117]. This procedure requires a scientist to observe the dynamics of (his / her) doings, otherwise neither physics nor chemistry nor any other science would be able to validly explain the reality of our life, or rather, living.

Thus, it appears that any science is meant to observe phenomena as experiences rather than objects 'out there', and it proves valid as long as it is experientially grounded, i.e. it can provide explanation of how, when and where this or that experience can recur without fail. In this respect, linguistics should pursue the same objectives. The present article will discuss why it does not happen and why mainstream theory of language has a too heavy legacy of Aristotle's analytical logic to focus on human experience lived in the dynamics of communication. There will also be given a methodological alternative of studying cinema as language-in-motion which may help the language science to move from the (mono-)logical, textoriented stance towards the eco-logical and experiential one.

Why linguistics tends to study static objects. Per Linell [2005] in his provocative critique of linguistics gives 101 reasons why mainstream linguistics chooses to approach language as literacy and the art of alphabetic writing rather than as human's natural bodily behavior situationally embedded in the social and cultural environment. He explains how linguists have become biased in their research towards written, static texts ever 
since literacy began to play a big cultural and even political role. States have needed standardized national languages to stand out in the political arena, societies have needed educated people with good writing skills. Moreover, literacy has always served as a social distinction between those who can speak the proper and correct language and those who speak the vulgar vernacular. Language issues thus stand 'proxy' for wider social issues [Rickford, 1999, p. 272]. "Inscriptions, in the concrete sense of static marks on paper, have been the dominant technology of language. At the same time, it is in the development of literacy, in the schooling needed for learning to read and write, that theories of language structure have become necessary" [Linell, 2005, p. 5].

According to Linell, the age-long tradition of language studies is characterized by scriptism, i.e. the influence of writing on the conceptualization of speech. Speech is a dynamic activity distributed in real time with both speaker and listener being physically present in the immediate context, while texts are offline, displaced and deferred. In terms of the dialogical property of interactivity, the written text is "suspended dialogue" [Peters, 1999] lacking any immediate situational context [Linell, 2005, p. 21]. Suffice it to say that writing and reading belong to the so-called secondary socialization, while the primary empirical interactions in the form of speaking and hearing are overshadowed in texts.

Thus, the structure of speech, or talk-ininteraction, is mainly studied from the perspective of its regular counterparts in conventional writing. Even those linguistic disciplines concerned with the grammar or pragmatics of spoken language treat utterances (a unit of speech) in comparison to sentences (a unit of text) and analyze what is analyzable textually ('spoken texts' or 'spoken grammar'). For example, utterances which do not display full clause structures are interpreted as 'elliptical', i.e. incomplete, lacking explicit proposition or even dysfunctional. In fact, any utterance in a spoken interaction may be called 'elliptical' because it is natural for participants in a dialogue to exploit properties of each other's utterances and thereby dynamically co-construct meanings and attitudes [Bakhtin, 1981]. Another case in point is gestures. Gestures cannot be (fully) represented in writing, that is why their role in language analysis is often minimized. Indeed, gestures, bodily postures, facial expressions, gaze behavior are perfectly integrated with verbal conduct. Alongside with linguistic features, gestures help people construct meanings and attitudes and "exploit features of the built environment" [Goodwin, 2000].

It follows that the main methodological gap in scriptism as posited by Linell and his supporters is the failure to depart from dualism. The desire to look at isolated structures as if independently existing objects is a hallmark of the Cartesian philosophy which dualizes our understanding of the world in terms of subject-object relationships. This tradition has persisted in linguistics ever since literacy made it possible to observe inscriptions, marks and other textually demarcated symbols on paper. With writing, language becomes a static, 'photographic' (or rather, representational) object existing 'out there'. "Linguists are not dealing with complex bodily conduct, behaviors, which exhibit recurrent structural properties. <...> Instead, they hypostatize, arrest, paralyze language structures as a body of knowledge, posit them as abstractions existing in and of themselves" [Linell, 2005, p. 9]. Another epistemological trap of scriptism is rationalism. Written texts are by definition logically organized intellectual products because writing is a purely linear affair. Studying texts linguists tend to find explanation not for what, how and why the author organized in his / her writing (it is physically impossible, as the context of writing is never observable), but for how the author's writing can be described and thus logically organized once again. In such a way, mainstream linguistic theory aims to establish double logical coherences which are detached from the reality of our perceptual acting in the immediate context.

The overview of scriptism in linguistics allows us to arrive at one important conclusion: language studies are basically associated with textology; generalizations made by linguists as a result of their observations of speech are grounded mainly upon what is or is not common to see on paper, not in life. Indeed, language goes far beyond writing. If it were not the case, illiterate people would either be proclaimed a miracle or considered non-linguistic at all.

From texts to experiences. In his studies of children's cognitive development, Leo Vygotsky became the first Soviet scientist who proved that language should not be approached analytically, because language is synthesis by definition. 
Language, he maintained, is not what we write, nor what speak, but is what we do towards, in and through writing, speaking or any other social and cultural interaction. According to Vygotsky, "to understand another's speech, it is not sufficient to understand his words - we must understand his thought. But even that is not enough - we must also know its motivation" [Vygotsky, 1962, p. 151]. He claims that traditional methods of verbal definition, by which he evidently meant describing things, are totally "inadequate for studying concepts... as they overlook the dynamics and the development of the process of concept formation" [Vygotsky, 1962, p. 96]. To find a term or definition for a concept is to deal with ready-made knowledge as the resulting product rather than the process of thinking or knowing. This method also confines research material to isolated verbalizations as the only source of empirics.

There are two important implications of this finding. First, language with all its structures, components or units cannot be investigated from within these units - it requires a much more holistic effort. Namely, we must look at the generative source of language, the process that takes place in a domain other than the domain of definitions or terms (cf.: [Maturana, Verden-Zöller, 2008, p. 154]). Second, we must integrate our abstractions back into the dynamics of bodily experience to check how they fit the conditions of our living.

Experiential view of language underlies the philosophy of enactivism in which language is equated with the operational dynamics of experience construction, or enactment of the world [Piaget, 1937; Varela, Thompson, Rosh, 1993; Glasersfeld, 1995]. There can be given three reasons to prove this point. First, "experience that which we distinguish as happening to us and in us - cannot be denied" [Maturana, VerdenZöller, 2008, p. 13]. Second, language is the root of all experience, i.e. all things happening to us and in us, since "the language I speak is my language, it makes me aware of myself" [Foerster, 2003, p. 297], it makes me an experiencer. Third, experience or language is not something readymade or passively received. It is actively constructed and organized in the course of cognitive development. Otherwise, we humans would not need to learn or live anything, instead we would be a machine waiting to be adjusted for the reception of the right signal.
What would be more appropriately termed as languaging is thus a cycle of changes happening to/in our body to reciprocally maintain the continuity of our focused and unfocused attention on "a sort of universe we shall appear to ourselves to inhabit" [James, 1890, p. 401]. The fact that our attention can be unfocused on some sensorial data and be still 'experientially active' is crucial for us humans: our attention once focusing on a perceptual item can refocus on it later by some power of volition and through recognition matrices [Ceccato, Zonta, 1980; Glasersfeld, Ackermann, 2011] which all, in turn, are made possible in and through languaging only [Kravchenko, 2016]. In this way we construct our experience out of the attentionally organized sensorial data, or else, our experiences. They are what we can easily isolate (abstract) from the sensorial flow, displace, or turn upon themselves (reflect upon them), and live again (enact) in a new context of interactions. Thus, languaging as experience construction can be characterized by the following ecology of enaction:

framing (isolating certain items from the bodily dynamics) + reference (interacting with these isolations: reflecting upon them and acting upon these reflections) + attention (selection of frames and their reference through changing interests and desires, or relations).

Thus, to study reference frames, what we commonly understand as names as well as their constellations - texts, means to study experiences, i.e. probe into our bodily operations (sensorimotor functioning and thinking processes) and their attentional triggers (relations).

\section{Method of investigation of experiential dynamics in linguistic research}

The dynamics of languaging as attentional and referential framing makes our living cognitively 'eco-logical'. It means that we operate in such an ecology where our interests and desires, our attentional processes determine our bodily actions and operations (thinking, moving, sensing), and vice versa. It means that every doing of ours changes a relation in which our next doing occurs; every decision we make, every word we say is related to our previous experience and can be adequately understood only in relation to this experience. If, for instance, you move your hand from a basin of 
cold water into one that is tepid, the second feels hot; if you begin with hot water, the tepid feels cold; the true temperature of the water, therefore, cannot be determined because our judgment depends on the experiential context.

It follows that the object of linguistic study should be a frame of reference as an item of experience enacted in the operational bodily dynamics under certain contextual conditions. To investigate such an object, we must rely upon two methodological techniques by which we (1) analyze a frame in one domain of observable doings, as an action performed by the agent in relation to something or someone (what exists out there), and (2) synthesize all the accessible epistemological, psychological, and even physiological data to look at this frame in another domain, as an interaction between the agent and his / her relations (his / her experiential reality as what he / she distinguishes as existing out there).

Thus, a hypothesis about a frame of reference as a linguistic abstraction must be based on the explanation of what, how, when and where we do 'to make this reference happen'. It implies looking at the practical context of interactions in which this frame of reference is enacted to construct experience.
One way to do this is to study children at different times of their cognitive development. A problem may arise because interrelated complexes in languaging do not take shape by default but are actively constructed and tested through trial and error over a course of time when, later, they become a more or less stable and sustainable structure or pattern of action.

Another path to approach direct experience in its perceptual, empirical sense is to explain the circumstances under which it is enacted as an abstraction, or else, re-enacted as an already viable and stable conceptual structure, internalized pattern of action. In explaining the circumstances (when, where, why?) we will also be able to identify the mechanisms (how?) underlying this cognitive enactment. Such mechanisms are epistemological ways of concept construction in and through abstractions, generalizations, and reflections (for a detailed account see: [Piaget, 1937; Glasersfeld, 1995]).

For the sake of clarity, I have summarized the procedural components of open-ended experiential analysis after Varela et al. [1993] and Glasersfeld [1995] and propose the following stepby-step question-answer algorithm of scientific observation and explanation of languaging-asexperience-construction (see Table 1).

\section{Table 1. Methodological algorithm of holistic research and open-ended experiential analysis of} language

(Step 1) Hypothesizing: What experience is enacted in/through a particular frame of reference?

(Step 2) Observation and analysis: When / where is it enacted?

What are the experiential circumstances driving one to refer to this experience? What new emerging experiences and emotional perturbations 'here and now' cause one to recreate the old experience in question?

(Step 3) Observation and analysis: Why is it enacted?

What kind of desired result does one seek to achieve? What kind of experiential balance does one strive to restore?

(Step 4) Observation and analysis: How is it enacted?

What operations does one do to experience something again?

- Is it a direct experience that is acted out almost automatically, without much thinking? (= Do I enact an empirical abstraction from raw sensory material?)

- Is it an indirect experience, i.e. one not only enacts an isolated item of (abstraction from) raw sensory material, but also reflects upon it to an extent that the experience is not re-created as it was?

- How exactly does one reflect upon the abstracted sensory material?

- Does one reflect upon the way one has this experience? (Does one change and develop an understanding of an experience to figure out how else one can have this experience? = Do I enact a reflective abstraction?)

- Does one reflect upon the way one abstracts this experience? (Does one change or develop one's understanding of understanding an experience = Do I enact a reflected abstraction?)

(Step 5) Synthesis and verification of the hypothesis: Does the hypoth esis work? Is the hypothesized experience enacted in the observed circumstances non-controversially? Can the deduced hypothesis predict the happening of the experience under the circumstances similar to those observed? How is the investigated experience distinguished from other phenomena? What is a better term for the investigated experience? 


\section{Results and discussion}

\section{Motion pictures as enactive data for linguistic research}

Why a picture in motion is better than a picture in isolation. To be able to grasp the dynamics of languaging, we should find ways to observe the experiential context of our semantic interactions, or else, our semantic living [Maturana, 2006]. The reason why it is not enough to study and describe language in its semantic abstractions is because isolated linear structures will never 'tell us the whole (holistic) story': they can only help de-fine, de-termine, find limitations to what we set out to observe (cf. step 1 in our methodological algorithm).

Motion pictures provide more or less reliable data for investigating languaging processes because in films we see what people do and how they act, not just what they say. More than that, we can observe the movement of people's (fictitious characters') attention in their thinking about what is displaced from the immediate perceptual field. The latter becomes possible in such a special form of filmed interactions that is directed, i.e. when somebody (a film director) takes responsibility for the viewers' holistic perception and understanding of what is happening on the screen. In other words, in a feature film, somebody's living is projected as a complete, meaningful story of which a viewer is expected to make some whole sense. The experiential context in such a story is always thorough enough to rely upon because every doing of the character is shown as preceding from, and proceeding to, another doing of his / hers. All interactions of the character stand in some generative relation to each other, that is why the context of each interaction, in our case - referential and attentional framing, can be made easily explicit rather than speculated upon. Thus, motion pictures provide data on 'living through talking', acting upon language while other semantic data offer us mainly talks about talking, texts in and of themselves.

I will try to make it more explicit why motion pictures go beyond familiar textual data and are useful in any linguistic research which is aimed at studying experience.

1. Uninterrupted non-linear dynamics: films help follow non-linear cognito-perceptual changes as they unfold in the human mind. There are no visible textual demarcations hindering us from experiencing the projected flow of living as it is. Motion pictures are free from the bias of linear written language where a reader is tempted into becoming a researcher by looking at structures and dialogical practices in isolation, as static product-oriented objects on paper [Linell, 2005] admitting of reading and rereading.

We should remember that repeating an experience or interrupting the experiential flow is another experience. The director will never replay a series of shots for no particular reason, the director will make this replay a part of the continuous experiential flow as planned and determined by the story. Under ordinary circumstances, a viewer in the cinema cannot stop the movie and go back to the previous shot or the titles unlike a reader who sometimes has to refer to the footnotes, appendices, etc. The author of a book may choose to diverge from the narrative by introducing philosophical reflections that have little to do with the experiential dynamics of the character. The director of a film is unable to show anything but the flow of attention and experience of the characters or / and narrator in the projection of their living. In this way film watching can guarantee natural conditions for non-linear uninterrupted experiential dynamics.

2. Broader contextuality: it should be once again stressed that in films we can observe practical, empirical domains of every semantic operation, while in texts we are confined to the semantic domain of the same semantic operations. Communication like any other interaction must be observed and scientifically explained across the domains of 'action in' and 'action out' (or generative mechanism and resulting process), otherwise what we would be observing and explaining is not an inter-action.

Even if we rely on data from corpora, what we will be studying in the final analysis are written texts, transcripts as linear affairs. Even if we find instances of spoken communication, we will not be able to make explicit the actual conditions in which the interaction in point occurred. As objects of study, texts are always bounded, while experiential background to the object of our study is never bounded; therefore, (experiential) context is not wholly observable in texts. To hypothesize about the experiential nature of this or that 
semantic structure, we should go deeper into the person's emotioning, thinking, and sensorimotor being in language. To make it possible, we must make sure we get ahold of the person's relevant semantic living in totality. How can we make sure what is relevant and what is not in written texts?

3. Distinctions between thinking and perceiving at one time: as a rule, films project not only something a character is perceiving, but also something a character is thinking. The director's camera not only frames the perceptual dynamics of the character's (or someone else's) body, but it also captures the flow of attentional focalizations through which the character selects ways of relating the perceived dynamics to his / her earlier experiences. It means that films allow one to observe attentional processes that are unobservable in normal conditions (even in psychological experiments), let alone in texts (where we do not directly observe anything, but are engaged in reading only). Such a narrative technique of the moving image helps the viewer not only 'experience' the character's living as it is, in the flow, but also follow the process of reality construction in the character's world.

4. Embodiment of knowing: films, as said before, project sensorimotor dynamics, thus making bodily movements (gaze, gestures, etc.) and sensoriality (hearing, seeing) observable.

A case study: a concept of time reversibility in/through counterfactuals. To demonstrate how effectively motion pictures can be methodologically applied to linguistic research, I will give one example that is connected with the study of some fundamental concepts and grammatical problems connected with them. The concept of time, in particular, can be easily approached from a dynamic perspective in which we can more clearly see the experiential context of time as a way of acting and then deduce (or even observe) the attentional and referential mechanisms underlying this acting. A choice of those films which tell their story around or throughout changing temporal reality will help. For instance, Atonement (2007) is interesting in this sense.

It is an if-only-I-had-not-done-it or itwould-have-happened-differently story about undoing the irreparable damage the main character once caused to her loved ones. Right from the point of dramatic and critical decision to wrongfully testify against her sister's boyfriend and get him imprisoned amid the waging World War II, Briony begins to live a life which will never get back to normal. Her sense of guilt and regret are portrayed as reflections upon the lived past which repeatedly interrupt the linearity of her experiential flow as well as the film's storytelling. Her attention is refocused on the earlier experiences and these refocalizations are often shown in reverse order to emphasize her desire to 'restore' the past. In the end she manages to beg forgiveness from her sister and her boyfriend, but later we see that this never happened and was part of her imagination. The people she betrayed were killed in the war. It appears that the bigger part of the story was told counterfactually, from the as-if perspective. Overwhelmed by the irreversible consequences of her light-minded behavior (her sister and her boyfriend's death), the main character has created a reality of her own (that comes out as another narrative) and acts upon it to cope with a sense of guilt. Throughout this reality she repeatedly goes back to the moment of the regrettable wrongdoing, enacting the "if-only-it-had-happened-otherwise" cognitive program. This, in turn, illuminates the cognitive mechanism of experience construction in terms of counterfactuals (or the subjunctive, in their linguistic abstraction).

The film director uses a number of techniques to portray Briony's experience, among which flashback reversion is of the greatest interest. It visualizes the reverse motion of the mind, the refocalization of the character's attention on some earlier salient experience. In particular, the farewell scene of Brinoy's sister (Cecilia) parting with her (Cecilia's) boyfriend at the doorstep of her mansion at the beginning of the film is shown in reverse order in the middle of the film to highlight the relational change which has happened in Briony's mind. This change of value occurred right after the fatal mistake she made to get her sister's boyfriend (Robbie) imprisoned and later killed in the war. She recognized this tragical mistake and now goes back to the lived experiences and replays them in reverse order. In doing so, the narrator (Briony) decides to construct a positively valued reality (the reality of begging forgiveness) which dominates the narrative and appears as a true story until her confession in the final scene. At the end of the 
film we see older Briony who has just finished a novel Atonement about Cecilia and Robbie. She says that her sister and Robbie reunited only in the book, in reality they died and Briony never met them to claim forgiveness after what happened when she was a mindless teenager. Briony's confession is shown to us as two sequences of moving images, the one is a negative reality of Robbie and Cecilia dying in the war, the second one is a positive, desired reality of Robbie and Cecilia enjoying their holiday by the seaside together.

The analysis of how older Briony's mind 'moves' in her reflections on the past as shown by the director in the last scene suggests that the realities constructed are not of the 'more true' or 'less true' kind, they belong to one and the same level of actuality of the storyline: they both are objects of Briony's attention. Both the death and the happy life of her sister are depicted sequentially. Their counterfactuals status emerges as a new understanding of the past and a change of relation Briony produces in her actuality ('here and now', at the moment of answering the interviewer's questions, at the moment of regretting her mistakes and getting more dissatisfied with her present life), not in the 'irreal' world.

The enactive data provided in the motion picture allow us to look at counterfactuals as a way of semantic living rather than a grammatical construction or logico-semantic structure. Briony lived a 'counterfactual life' throughout the second half of the story. Counterfactuals became for her a way of dealing with her sense of guilt, with the world that tragically changed for her the moment she made a life-changing decision to testify against her sister's boyfriend. She enacted counterfactuals in and through her reflections upon the past where she re-organized the past experience by changing the relational value of this experience from the negative to the positive. The summary of our findings are given in Table 2 .

The findings will help us make a few linguistic generalizations on counterfactuals. Linguistically, counterfactuals are frames of reference in which the agent reverses the past time, or rather, his / her lived experiences, to counterbalance what he / she is actually living in the present. In other words, the value of the lived experience is not satisfying for the agent to live on and anticipate the coming changes in a normal, linear direction; he / she begins to (reflectively) change the direction of this experiential flow and act upon this change by constructing new experience out of the old one.

This complex, non-linear process of attentional and experiential counterbalancing may well explain the complex and non-linear grammatical choices we make in our languaging.

\section{Table 2. Counterfactuals as an experience (a case study of Atonement)}

\begin{tabular}{|c|c|c|}
\hline Step & Research Procedure & Results \\
\hline Step 1 & Hypothesizing & $\begin{array}{l}\text { time is specifically experienced in/through a counterfactual way of dealing with } \\
\text { the world }\end{array}$ \\
\hline Step 2 & $\begin{array}{l}\text { Observation and analysis: } \\
\text { when / where? }\end{array}$ & $\begin{array}{l}\text { the experience is enacted after the character's fatal mistake, in the circumstances of } \\
\text { repentance and atoning }\end{array}$ \\
\hline Step 3 & $\begin{array}{l}\text { Observation and analysis: } \\
\text { why? }\end{array}$ & $\begin{array}{l}\text { the experience is enacted to deal with a sense of guilt, to beg forgiveness from } \\
\text { the wrongfully betrayed people }\end{array}$ \\
\hline Step 4 & $\begin{array}{l}\text { Observation and analysis: } \\
\text { how? }\end{array}$ & $\begin{array}{l}\text { The experience is enacted } \\
\text { attentionally: through refocalizations on the lived experiences, the refocalizations } \\
\text { counterbalancing (helping to restore the balance in) the dynamics of the actual } \\
\text { living; } \\
\text { cognitively: through reflecting upon what happened in the past and acting upon } \\
\text { this reflection (constructing a new experience by reverting the way the past } \\
\text { experiences happened); } \\
\text { relationally: through a change of value attached to the lived experience }\end{array}$ \\
\hline Step 5 & Synthes is and verification & $\begin{array}{l}\text { The investigation fits the following hypothesis: } \\
\text { a concept of time reversibility is enacted in/through counterfactuals; the experiential } \\
\text { result (the enactment) is counterbalancing reality }\end{array}$ \\
\hline
\end{tabular}


Namely, the pattern If I only I had not done such a mistake, everything would have happened differently involves a number of complicated and 'illogical' structures for a reason. Contrasting negation (If I had ... = in fact, I don't have) helps to create a relational change and reverse the experience, past tense forms specify what kind of the lived experience we are reversing (in a reflective abstraction) and 'future-in-the past' would frames the result of this reversion, namely the construction of a new, counterbalancing experience. All in all, the counterfactual enactment of the world creates counterbalancing reality in referential frames of which we act to satisfy our changing interests and desires.

To sum it up, the motion picture provided significant data for a holistic understanding of experience construction in terms of non-linear temporal reality. Different techniques of film making and our holistic perception of the story, the character's living, rather than his / her talking, assured a maximum of methodological integration in the observation and synthetical study of languaging.

\section{Conclusion}

Motion pictures remain a good source of enactive data for linguistic research unless they are treated as texts. If they are, linguists find themselves "epistemologically trapped in the fragmentary understanding of language, culture and cognition" [Kravchenko, 2016]. Texts will never provide a whole picture of what human language is because in texts a human cannot be observed. In particular, texts are what we have already produced in the process of our experience organization, but they are far from this process itself, they have very little to say about how, where and when we organize our experience. If we cannot investigate such factors, we cannot construct a valid hypothesis about this or that experiential item generating our recurrent communicative behavior, or languaging dynamics. If we cannot do so, we fail to meet the requirements of scientific research to explain "how something works always".

Viewed holistically, motion pictures can safely be used in the study of languaging as experience construction because in them we can observe actors acting upon, and enacting, bodily dynamics. Just as our 'moving' attention selects some part of our perceptual field to frame for reference, the moving camera selects an image to capture for the meaningful development of the story. Just as the flow of our living causes us to construct meaningful experience by relating one experiential item to another, the developing story of a film makes sense to let one event happen after, before or during another. Just as for a scientific understanding of reality we explain the recurrent coherences of our experiential dynamics across separate relational domains, films allow us to look at the experiential dynamics of the characters in totality which gives us a better understanding of the latter's behaviors.

Linell expresses hopes that computersupported visualization of languaging dynamics will offer a methodological alternative to the productoriented approach of mainstream linguistics [Linell, 2005 , p. 220]. Some work has been done in this regard with Druzhinin et al. [2020] attempting to investigate such relational phenomena as dysphemisms and euphemisms in experiential contexts on the basis of TV drama shows and concluding that the distinction between the 'phemes' depends upon the experience of the distinguisher. A lot of work is still to be done in the area of linguistic and cross-disciplinary research, and once we approach language in experiential totality, as where and how we humans organize our being, we will be able to write the long sought-after linguistic "recipes that work always".

\section{REFERENCES}

Bakhtin M.M., 1981. The Dialogical Imagination: Four Essays by M.M. Bakhtin. Austin, University of Texas Press. $480 \mathrm{p}$.

Bridgman P.W., 1958. The Logic of Modern Physics. New York, Macmillan, vol. 3. 246 p. (First Published in 1927).

Ceccato S., Zonta B., 1980. Linguaggio, Consapevolezza, Pensiero. Milan, Feltrinelli. 269 p.

Druzhinin A.S., Fomina T.A., Polyakov O.G., 2020. Evfemizmy, disfemizmy, ortofemizmy ieksperientsialnyi kontekst: kholisticheskii vzglyad na lingvisticheskuyu problemu [Euphemisms, Dysphemisms, Orthophemisms and Experiential Context: A Holistic View of the Linguistic Problem]. Yazyk i kultura [Language and Culture], no. 50 (2), pp. 23-40. 
Foerster H. von, 2003. Understanding Understanding: Essays on Cybernetics and Cognition. New York, Berlin, Springer Science \& Business Media. $362 \mathrm{p}$.

Glasersfeld E. von, 1995. Radical Constructivism: A Way of Knowing and Learning. Bristol, Falmer Press. 213 p.

Glasersfeld E. von, Ackermann E.K., 2011. "Reflections on the Concept of Experience and the Role of Consciousness". Unfinished Fragments. Constructivist Foundations, no. 6, pp. 193-203.

Goodwin C., 2000. "Action and Embodiment Within Situated Human Interaction". Journal of pragmatics, no. 32, pp. 1489-1522.

James W., 1890. Principles of Psychology. New York, Henry Holt and Company, vol. 1.716 p.

Kravchenko A.V., 2016. Constructivism and the Epistemological Trap of Language. Constructivist Foundations, no. 12, pp. 39-41.

Linell P., 2005. The Written Language Bias in Linguistics: Its Nature, Origins and Transformations. London, Routledge. $256 \mathrm{p}$.

Maturana H., 1988. Reality: The Search for Objectivity or the Quest for a Compelling Argument. The Irish Journal of Psychology, no. 9, pp. 25-82.
Maturana H., 2006. Self-Consciousness: How? When? Where? Constructivist Foundations, no. 3, pp. 91-102.

Maturana H., 2012. Reflections on My Collaboration with Francisco Varela. Constructivist Foundations, no. 7, pp. 155-164.

Maturana H.R., Verden-Zöller G., 2008. The Origin of Humanness in the Biology of Love. London, Andrews UK Limited. 252 p.

Peters J.D., 1999. Speaking into the Air: A History of the Idea of Communication. Chicago, University of Chicago Press. 304 p.

Piaget J., 1937. La Construction du Réel Chez L'Enfant. Neuchâtel, Delachaux et Niestlé. 345 p.

Rickford J.R., 1999. The Ebonics Controversy in My Backyard: A Sociolinguist's Experiences and Reflections. Journal of Sociolinguistics, no. 3, pp. 267-275.

Valéry P., 1957. OEuvres. Paris, Bibliotheque de la Pleiade. 1872 p.

Varela F.J., Thompson E., Rosh E., 1993. The Embodied Mind: Cognitive Science and Human Experience. Massachusetts, MIT Press. 309 p.

Vygotsky L.S., 1962. Thought and Language. Cambridge, Massachusetts, MIT Press. 168 p.

\section{Information About the Author}

Andrey S. Druzhinin, Candidate Sciences (Philology), Associate Professor, English Language Department no. 3, MGIMO University, Prosp. Vernadskogo, 76, 119454 Moscow, Russia, andrey.druzhinin.89@mail.ru, https://orcid.org/0000-0001-9971-4019

\section{Информация об авторе}

Андрей Сергеевич Дружинин, кандидат филологических наук, доцент кафедры английского языка № 3, Московский государственный институт международных отношений (университет) МИД России, просп. Вернадского, 76, 119454 г. Москва, Россия, andrey.druzhinin.89@mail.ru, https://orcid.org/0000-0001-9971-4019 